\title{
Increased tumour necrosis factor $\alpha$ production by neutrophils in patients with hepatitis $B$
}

\author{
X Fan, Z Zhang
}

\begin{abstract}
Aims-To investigate the role of serum and neutrophil tumour necrosis factor $a$ (TNFa) in patients with viral hepatitis Methods-The activities of serum and neutrophil TNF $a$ were measured using a bioassay of in vitro cytotoxicity against L929 cells in 57 patients with viral hepatitis and 20 healthy blood donors.

Results-Both serum and neutrophil TNFa in patients with chronic active hepatitis (CAH) and subacute fulminant hepatitis (SAFH) increased compared with those in normal controls $(p<0.01)$. No such differences were seen in patients with acute hepatitis. Serum and neutrophil TNF $\alpha$ were obviously reduced in patients with CAH and SAFH during convalescence compared with the active period ( $p<0.05 ; p<0.01)$. Furthermore, serum TNFa was significantly increased in patients with SAFH and complications compared with those without $(p<0.01)$, and in patients with SAFH who died compared with those who survived $(p<$ 0.01). Neutrophil TNFa was significantly higher in patients with SAFH and secondary bacterial infections $(p<0.05)$. Conclusions-Production of serum and neutrophil TNFa is increased in patients with CAH and SAFH, suggesting that neutrophil TNFa causes liver injury in these patients.
\end{abstract}

(F Clin Pathol 1994;47:616-618)

Tumour necrosis factor $a(\mathrm{TNF} a)$ is a cytokine which mediates many important biological actions. ${ }^{12}$ Many experimental and clinical studies have shown that TNFa has a pivotal role in hepatocyte necrosis, including alcoholic hepatitis, viral hepatitis, and galactosamine liver damage. ${ }^{3-5}$ Dubravec et al recently found that peripheral blood neutrophils can also synthesise and secrete TNF $a .^{6}$

Although there have been some reports on the importance of monocyte or macrophage derived TNF $a$ in liver cell necrosis, ${ }^{37}$ the activity of neutrophil TNF $a$ in patients with hepatitis and its role in the pathogenesis of liver injury in viral hepatitis are unknown. To evaluate the role of neutrophil TNF $a$ in patients with viral hepatitis, we measured basal and lipopolysaccharide (LPS)-stimulated $\mathrm{TNF} a$ concentrations in peripheral blood neutrophils, a new source of TNF $a$ production, using a bioassay.

\section{Methods}

Fifty seven inpatients (13 women, 44 men, 20-54 years old) with various clinical types of viral hepatitis were studied. All had hepatitis B (HBV) except nine subjects diagnosed with hepatitis A, all of whom had acute hepatitis. The serological profiles of patients with hepatitis $\mathrm{B}$ were $\mathrm{HBsAg}$ and $\mathrm{HBeAg}$ positive, or $\mathrm{HBsAg}$ and anti-HBc positive, or $\mathrm{HBsAg}$, $\mathrm{HBeAg}$, and anti-HBc positive. Serum HBV DNA was positive in 42 of 48 patients with $\mathrm{HBV}$ infection. The clinical types of patients were defined according to clinical signs and the results of liver function tests and liver histology.

Twenty healthy blood donors (11 women, nine men, 22-41 years old) with negative serum markers for hepatitis $A, B$, and $C$ virus, and normal liver function tests were used as normal controls.

Peripheral blood neutrophils were isolated from anticoagulated venous blood by dextran sedimentation and Ficoll-Hypaque gradient and the residual erythrocytes were removed using hypotonic water lysis. ${ }^{6}$ Neutrophils $\left(1 \times 10^{6}\right.$ cells $\left./ \mathrm{ml}\right)$ were suspended in RPMI1640 medium containing $10 \%$ complement inactivated fetal calf serum, $20 \mathrm{mM}$ L-glutamine, $100 \mathrm{U} / \mathrm{ml}$ penicillin, and $100 \mu \mathrm{g} / \mathrm{ml}$ streptomycin. Neutrophil purity was $97 \%$ by Giemsa stain and the viability was $99 \%$ by tryptan blue exclusion.

Neutrophils $\left(1 \times 10^{6} / \mathrm{Well}\right)$ were seeded into 24-well cell culture plates. Duplicate cultures were incubated either in the above medium or medium plus lipopolysaccharide (Sigma, final concentration $5 \mu \mathrm{g} / \mathrm{ml}$ ) at $37^{\circ} \mathrm{C}$ and a $5 \% \mathrm{CO}_{2}$ environment. After 24 hours culture supernatant fluids were collected and stored at $-70^{\circ} \mathrm{C}$ for $\mathrm{TNF} a$ activity assay. Serum samples from patients and controls were obtained simultaneously and stored at $-70^{\circ} \mathrm{C}$.

Monocytes and macrophages were also isolated from normal controls by adherence of Ficoll-Hypaque-separated mononuclear cells to plastic Petri dishes for two hours at $37^{\circ} \mathrm{C}$ and stimulated in the same way except that they were cultured at a final concentration of

Table 1 Mean (SD) TNFa activities in normal controls (U/ml)

\begin{tabular}{lcll}
\hline $\begin{array}{l}\text { Age } \\
\text { (years) }\end{array}$ & $\begin{array}{l}\text { No of } \\
\text { cases }\end{array}$ & $\begin{array}{l}\text { Serum } \\
\text { TNFa }\end{array}$ & $\begin{array}{l}\text { Neutrophil } \\
\text { TNFa }\end{array}$ \\
\hline 20 & 7 & $8 \cdot 86(3 \cdot 98)$ & $6 \cdot 0(3 \cdot 06)$ \\
30 & 10 & $9 \cdot 11(3 \cdot 02)$ & $6 \cdot 44(2 \cdot 19)$ \\
40 & 3 & $6 \cdot 0(2 \cdot 0)$ & $4 \cdot 67(1 \cdot 15)$ \\
Total & 20 & $8 \cdot 50(3 \cdot 24)$ & $5 \cdot 90(2 \cdot 38)$ \\
\hline
\end{tabular}

\author{
Correspondence to: \\ Dr Xuegong Fan, SPD \\ Research Laboratory, St \\ College, Dublin 8, Ireland \\ Accepted for publication \\ 14 December 1993 \\ Infectious Diseases, \\ China) Hospital \\ Hunan Medical \\ University, Changsha, \\ Hunan, China
}


Table 2 Mean (SD) TNFa activities in patients

\begin{tabular}{lllll}
\hline & & $\begin{array}{l}\text { Mean age } \\
\text { (years) }\end{array}$ & Serum & Neutrophil \\
\cline { 5 - 5 } & No of cases & 33 & $8 \cdot 27(3 \cdot 99)$ & $5 \cdot 60(2 \cdot 29)$ \\
Acute hepatitis & 15 & 38 & $17 \cdot 20(7 \cdot 47)^{\star \star}$ & $12 \cdot 40(6 \cdot 82)^{\star \star}$ \\
CAH & 20 & 39 & $28.0(18 \cdot 02)^{\star \star}$ & $17 \cdot 36(9.94)^{\star \star}$ \\
SAFH & 22 & &
\end{tabular}

Table 3 Correlation between serum and neutrophil TNFa

\begin{tabular}{llll}
\hline & No of cases & $r=$ & $p$ Valve \\
\hline Controls & 20 & 0.5803 & $<0.01$ \\
Acute hepatitis & 15 & 0.7307 & $<0.01$ \\
CAH & 20 & 0.8826 & $<0.01$ \\
SAFH & 22 & 0.4468 & $<0.05$ \\
\hline
\end{tabular}

$2 \times 10^{5}$ cells per well. This population represents one fifth of the total number of neutrophils that were similarly stimulated.

The activities of serum and neutrophil TNF $a$ were measured by bioassay of in vitro cytotoxicity against L929 cells. ${ }^{68}$ Briefly, L929 cells $\left(5 \times 10^{5} / \mathrm{ml}\right)$ were seeded into 55 well cell culture plates in $0.1 \mathrm{ml}$ per well and incubated at $5 \% \mathrm{CO}_{2}$, at $37^{\circ} \mathrm{C}$ for 24 hours. Spent medium was removed and L929 cells were washed. Sera or supernatant fluids of serial two-fold dilutions were added to each well in $0.1 \mathrm{ml}$, and actinomycin $\mathrm{D}$ (final concentration $1 \mu \mathrm{g} / \mathrm{ml}$ ) was added to all wells at the same time. Control wells contained lipopolysaccharide and actinomycin $\mathrm{D}$ only. After 24 hours of incubation at $37^{\circ} \mathrm{C}$ in a $5 \%$ $\mathrm{CO}_{2}$ atmosphere medium was removed and plates were stained with $0 \cdot 2 \%$ crystal violet in $0.1 \mathrm{ml}$ per well for 10 minutes. Excess stain was removed by washing in tap water. After drying, $1 \%$ sodium dodecyl sulphate was added to all wells, and absorbance determined at $570 \mathrm{~nm}$ using an enzyme linked immunosorbent assay (ELISA) reader (ME 891, China). Sample TNF $a$ activities were calcu-

Table 4 Serial observations of mean (SD) TNFa in patients

\begin{tabular}{lcccc}
\hline & $T N F a(U / m l)$ & & \\
\cline { 2 - 5 } & Serum & & Neutrophil & \\
\hline CAH n $=6$ & & & & \\
At admission & $20.0(9.47)$ & $\mathrm{p}<0.01$ & $16.67(9.61)$ & $\mathrm{p}<0.05$ \\
Convalescence & $9.0(4.69)$ & & $6.33(3.32)$ & \\
SAFH n = 8 & $23.0(11.66)$ & $\mathrm{p}<0.05$ & $17.50(13.34)$ & $\mathrm{p}<0.05$ \\
At admission & $13.50(8.26)^{\star}$ & & $6.75(3.37)$ & \\
Convalescence & 13.05 & & \\
\hline
\end{tabular}

${ }^{\star} \mathrm{p}<0.05$ compared with controls.

Table 5 Association between TNFa and clinical course in patients with SAFH

\begin{tabular}{|c|c|c|c|c|}
\hline & \multicolumn{4}{|l|}{$T N F a(U / m l)$} \\
\hline & Serum & & Neutrophil & \\
\hline $\begin{array}{l}\text { Secondary infections: } \\
\text { Yes } 11 \\
\text { No } 11\end{array}$ & $\begin{array}{l}39 \cdot 27(19 \cdot 08) \\
16 \cdot 73(6 \cdot 15)\end{array}$ & $\mathrm{p}<0.01$ & $\begin{array}{l}22 \cdot 36(12 \cdot 03) \\
12 \cdot 36(2 \cdot 80)\end{array}$ & $p<0.05$ \\
\hline $\begin{array}{l}\text { Complications }{ }^{\star} \text { Yes } 8 \\
\text { No } 14\end{array}$ & $\begin{array}{l}43.0(19.57) \\
19 \cdot 43(10.03)\end{array}$ & $p<0.01$ & $\begin{array}{l}20 \cdot 75(8 \cdot 94) \\
15 \cdot 43(10 \cdot 27)\end{array}$ & $p>0.05$ \\
\hline $\begin{array}{l}\text { Prognosis: } \\
\text { Died } 8 \\
\text { Survived } 14\end{array}$ & $\begin{array}{l}43.0(19.57) \\
19.43(10.03)\end{array}$ & $p<0.01$ & $\begin{array}{l}20 \cdot 75(8.94) \\
15 \cdot 43(10 \cdot 27)\end{array}$ & $p>0.05$ \\
\hline
\end{tabular}

^ Includes upper gastrointestinal haemorrhage, hepatorenal syndrome, and hepatic coma. lated as the reciprocal of the dilution resulting in $50 \%$ cytotoxicity.

Data were expressed as mean (standard deviation) and analysed using Student's $t$ test, the Mann-Whitney U test, and linear regression analysis.

\section{Results}

TNF $a$ ACTIVITY OF NORMAL CONTROLS

The mean (SD) serum TNF $a$ activities of normal men and women were $9 \cdot 11$ $(4 \cdot 14) \mathrm{U} / \mathrm{ml}$ and $8.0(2.37) \mathrm{U} / \mathrm{ml}$, respectively; the neutrophil TNFa was $6.67(2.64)$ $\mathrm{U} / \mathrm{ml}$ and $5 \cdot 27(2 \cdot 05) \mathrm{U} / \mathrm{ml}$, respectively. No significant differences were found between the two groups in serum or neutrophil TNF $a$ (p > $0.05)$. There were also no differences between the different age groups for serum as well as neutrophil TNFa activities (table 1). Neutrophil TNF $a$ concentrations were undetectable in culture supernatant fluids without lipopolysaccharide stimulation in 20 normal controls.

Secretion of TNF $a$ by monocytes or macrophages was also detected. The results showed that a quantity of monocytes equal to a fifth of the neutrophils produced significantly less TNF $a$. It was confirmed that the TNF $a$ determined in this study was produced by neutrophils.

\section{PATIENTS' TNF $a$ ACTIVITY}

The activities of serum TNF $a$ in patients with acute hepatitis $A(n=9)$ and with hepatitis $B$ $(\mathrm{n}=6)$ were $7.86(3.62) \mathrm{U} / \mathrm{ml}$ and 8.63 $(4 \cdot 16) \mathrm{U} / \mathrm{ml}$, respectively; neutrophil TNFa was $5.71(2 \cdot 78) \mathrm{U} / \mathrm{ml}$ and $5.59(2 \cdot 20) \mathrm{U} / \mathrm{ml}$, respectively. There were no significant differences $(p>0.05)$ between the two groups of acute patients for serum and neutrophil TNF $a$ activities. Both serum and neutrophil TNF $a$ activities in patients with chronic active hepatitis and subacute fulminant hepatitis were increased compared with those found in normal controls. No such differences were found in patients with acute hepatitis (table 2). TNF $a$ production of neutrophils without lipopolysaccharide stimulation was detectable in only three of 20 cases with $\mathrm{CAH}$ $(4,8$, and $4 \mathrm{U} / \mathrm{ml}$, respectively) and five of 22 cases with SAFH $(6,8,8,8$, and $4 \mathrm{U} / \mathrm{ml}$, respectively).

There was a significant correlation between serum and neutrophil TNFa activities (table 3).

Serum and neutrophil TNFa were obviously reduced in patients with $\mathrm{CAH}$ and SAFH during convalescence compared with the active period. However, serum TNF $a$ in convalescing patients with SAFH was still much higher than that of normal controls (table 4).

Serum TNF $a$ was significantly increased in patients with SAFH and complications, including secondary bacterial infections, upper gastrointestinal haemorrhage, hepatorenal syndrome and hepatic coma, compared with those free of these. This was also seen in patients with SAFH who died com- 
pared with those who survived. However, neutrophil TNFa was significantly higher in patients with SAFH and secondary bacterial infections as the only complication (table 5).

No correlations were found between the concentrations of serum or neutrophil TNFa and patients' weight, serum albumin, or numbers of peripheral blood neutrophils.

\section{Discussion}

The factors which cause liver cell necrosis in patients with hepatitis B are not fully understood, but clearly both the cellular and humoral immune responses of the hosts are important determinants. ${ }^{9}{ }^{10}$ Some studies have shown that TNFa, as a factor mediating liver injury, has a pivotal role in the pathogenesis of hepatic necrosis in patients with hepatitis B. ${ }^{411}$ However, the importance of TNF $a$ produced by neutrophils, and not monocytes or macrophages, has not been documented in such patients. We have shown that high activities of neutrophil TNF $a$ as well as serum $\mathrm{TNF} a$ were present in patients with $\mathrm{CAH}$ or SAFH, and were closely associated with the severity of the patient's condition. Our results lend further support to the important role TNF $a$ has in hepatocyte necrosis of hepatitis B. They also show that neutrophil TNFa is associated with liver injury. The concentrations of both serum and neutrophil TNFa were not increased in patients with acute hepatitis, including hepatitis A and B. This may be one of the explanations why severe hepatocyte necrosis occurs only in patients with CAH and SAFH and not in patients with acute hepatitis.

One of the most potent stimulators of $\mathrm{TNF} a$ release is endotoxin. Endotoxaemia occurs in patients with hepatitis, especially $\mathrm{CAH}$ and SAFH. ${ }^{12}$ Furthermore, recent studies have shown that most of the effects of endotoxin are mediated through cytokines, such as interleukin 1 (IL-1) and TNF $a .{ }^{513} \mathrm{We}$ propose, therefore, that endotoxaemia or secondary bacterial infections may be one of the causes for increased activity of neutrophil TNF $a$ in patients with CAH and SAFH. Our results showed that both serum and neutrophil TNF $a$ activities were much higher in patients with secondary bacterial infections than those without, further supporting the notion that increased TNF $a$ activity was at least partly induced by endotoxin stimulation.

Neutrophils from three patients with $\mathrm{CAH}$ and five with SAFH produced some TNFa without lipopolysaccharide stimulation. No evidence of bacterial infections was apparent in three patients with $\mathrm{CAH}$, but there was spontaneous bacterial peritonitis in five with SAFH. This might be explained by the possibility that the neutrophils were pre-activated in vivo, as a result of endotoxaemia. The bacterial contamination of samples should not be a factor because basal neutrophil TNFa was not found in normal controls or patients with concomitant acute hepatitis. The increase in serum TNF $a$ activity differed from the level of neutrophil TNFa activity in patients with complications and in those who subsequently died. One possible explanation is that serum TNF $a$ activity was influenced by TNF $a$ released from neutrophils in addition to that produced by monocytes or macrophages.

Despite numerous studies, the precise mechanisms for liver cell necrosis induced by TNF $a$ remain obscure. ${ }^{14}$ Several potential factors could be implicated. (i) TNFa, as an antiviral agent, can quickly lyse and cause necrosis of hepatocytes infected with HBV. When $\mathrm{HBV}$ is eradicated, massive liver cell necrosis occurs. ${ }^{14}$ (ii) TNF $a$ may promote the production of some oxygen free radicals, ${ }^{15} 16$ and it has been confirmed that oxygen free radicals can cause liver injury and necrosis. ${ }^{17}$ (iii) TNFa may stimulate release of other inflammatory cytokines, such as IL-1, IL-6, and IL-8, which can cause or aggravate liver damage. ${ }^{1819}$

1 Beutler B, Cerami A. Cachectin and tumour necrosis factor as two sides of the same biological coin. Nature $1986 ; 320: 584-8$

2 Malik S, Balkwill FR. Tumor necrosis factor. Br Med $\mathcal{f}$ 1988;296:1214.

3 McClain CJ, Cohen DA. Increased tumor necrosis factor production by monocytes in alcoholic hepatitis Hepatology 1989;9:349-51.

4 Muto Y, Nouri-Aria KT, Meager A, Alexander GJM, Eddleston ALWF, Williams R. Enhanced tumor necrosis factor and interleukin-1 in fulminant hepatic failure. Lancet 1988;ii:72-4.

5 Lehmann V, Freudenberg MA, Galanos C. Lethal toxicity of lipopolysaccharide and tumor necrosis factor in normal and D-galactosamine treated mice. $f$ Exp Med 1987;165:657-63.

6 Dubravec DB, Spriggs DR, Mannick JA, Rodrick ML Circulating human peripheral blood granulocytes syn-
thesize and secrete tumor necrosis factor $\alpha$. Proc Natl thesize and secrete tumor necrosi

7 Yoshioka K, Kakumu S, Arao M, Tsutsumi Y, Inoue M. Tumor necrosis factor $\alpha$ production by peripheral blood mononuclear cells of patients with chronic liver disease. Hepatology 1989;10:769-73.

8 Kramer SM, Carver ME. Serum-free in vitro bioassay for the detection of tumour necrosis factor. $\mathcal{F}$ Immunol Methods 1986;93:201-6.

9 Dudley FJ, Fox RA, Sherlock S. Cellular immunity and hepatitis-associated Australia antigen liver disease. Lancet 1972;i:723-6.

10 Eddleston ALWF, Williams $R$. Inadequate antibody response to HBsAg or suppressor T-cell defect in development of active chronic hepatitis. Lancet 1974;ii $1543-5$

11 Yoshioka K, Kakumu S, Arao M, Tsutsumi Y, Inoue $M$, Wakita T, Ishikawa T, Mizokami M. Immunohistochemical studies of intrahepatic tumour necrosis factor $\alpha$ in chronic liver disease. $₹$ Clin Pathol 1990 43:298-302.

12 Wilkinson SP, Arroyo V, Gazzard BG, Moodie H, Williams R. Relation of renal impairment and haemorrhagic diathesis to endotoxaemia in fulminant hepatic failure. Lancet $1974 ; \mathbf{i}: 521-4$.

13 Beutler B, Milsark IW, Cerami A. Passive immunization against cachectin/tumor necrosis factor protects mice from lethal effect of endotoxin. Science 1985;229: 869-71.

14 Aderka D, Levo Y. Does tumour necrosis factor play a role in the pathogenesis of fulminant hepatitis? Med Hypotheses 1988;27:193-6.

15 Larrick JW, Graham D, Toy K, Lin LS, Senyk G, Fendly BM. Recombinant tumor necrosis factor causes activation of human granulocytes. Blood 1987;69:640-4.

16 Slungaard A, Vercellotti GM, Walker G, Nelson RD Jacob HS. Tumor necrosis factor $a /$ cachectin stimulates eosinophil oxidant production and toxicity towards human endothelium. $¥$ Exp Med 1990;171:2025-41.

17 Arthur MJP, Bentley IS, Tanner AR, Saunders PK Millward-Sadler GH, Wright R. Oxygen-derived free radicals promote hepatic injury in the rat. Gastroenterology 1985;89:1114-22.

18 Fong Y, Tracey KJ, Moldawer LL. Antibodies to cachectin/tumor necrosis factor reduce interleukin 1 bet and interleukin 6 appearance during lethal bacteraemia. $\mathcal{F}$ Exp Med 1989;170:1627-33.

19 Sheron N, Williams R. IL-8 as a circulating cytokine: induction by recombinant tumor necrosis factor-alpha. Clin Exp Immunol 1992;89:100-3. 